\title{
Internet as an alternative media for Dalits in India: Prospects and challenges
}

\author{
C. Suresh Kumar ${ }^{1,}$ R. Subramani.Ph.D ${ }^{2}$ \\ ${ }^{1}$ Assistant Professor, Department of Visual Communication, Pondicherry University, Pondicherry - 605008 \\ India. \\ ${ }^{2}$ Assistant Professor, Department of Journalism and Mass Communication, Periyar University, Salem-636011, \\ Tamil Nadu, India.
}

\begin{abstract}
Internet has enormous power to bring social equality to the people neglected in the society. Internet has been widely used by the people living on the margin of the society as an alternative to the mainstream media.In India, Dalits comprise of more than 200 millions. But their socio, political and economic issues noticed by the mainstream media are miniscule in numbers. Thus, there is a need for the educated Dalit population to find an alternative media through which they can express and respond with outside world. In this scenario, internet has proved to be an avenue for educated Dalits. This paper analyses in detail about how internet platform such as Dalit websites, social media such as blogs are an alternative media to verbalize the issues of Dalits in India.This paper outlines the new opportunities for Dalits in the cyber space- online networks which accommodates the voice of the subaltern people and also maps the approaches of main stream media towards the issues of Dalits. The conceptual discussion on the issues has clearly exemplified the deplorable state of affairs of the coverage of Dalit issues by the mainstream media.
\end{abstract}

Key words: Dalits, alternative media, internet, mainstream media, caste

\section{Introduction}

Media has been under severe criticism from Dalit reformers for being manuwadi or casteist. Kanshi Ram, the founder of Bahujan Samaj Party (BSP) reiterated not to trust the upper caste media and encouraged for a voice for Dalits in the media (Ninan, 2007). Ever since the evolution of mass communication be it print or audio-visual media, Dalits tried to run their own media on a par with the rest of the media industry. But, owing to many factors they could not survive. The Hindu, a daily English newspaper, celebrated its $125^{\text {th }}$ anniversary on September 2003.Parayan, a Dalit magazine, which was started by the Dalit scholar Rettaimalai Srinivasan in the same year as that of The Hindudoes not find its existence today. Similarly many magazines were started by Dalit activists, but they eventually ousted as they could not withstand the caste politics (Ravikumar, 2007). Furthermore, economic conditions and caste supremacy did not allow them to sustain in the competitive media market.

One of the reasons as to why the Dalit media is not able to perpetuate its existence is the domination of the upper caste media. In India, most of the communication has been elite oriented and upper class monopolized in the field of communication. No wonder the Indian media was ranked number one in the hall of shame for being caste apartheid (Prasad, 2006). Most of the Indian broadcast media are owned by business houses who hail from upper caste. So, it is not surprising to note that they gave least preference to Dalit issues or recruited Dalits as journalists in their media. Thus, radio, television, cinema and newspapers were completely inaccessible media for Dalits as there were no Dalits to represent their issues. This conventional belief has been acknowledged by the researcher Robin Jeffery. The excerpts of his notes articulate that, "there were almost none in 1992, and there are almost none today: Dalits in the newsrooms of India's media organization". He calls this deplorable situation of the exclusion of Dalits in the mainstream media as "the betrayal of the constitutional guarantees of equality and fraternity" (Jeffery, 2012). Furthermore, Balasubramainam (2011) in his research paper narrates his experience where he was denied to get placed in one of the Tamil dailies as a journalist after having been enquired about his caste. In India, nearly 25 percent of the population makes up of Scheduled Castes and Scheduled Tribe, but we find news about them hardly appearing in the mainstream media. Though international media have picked up the discrimination issues and started taking about them, Indian media has not yet come openly to champion Dalits (The Hindu, April 9, 2012). In a recent online survey conducted among 210 respondents who access Dalit websites and blogs, the perception of mainstream media towards Dalit issues was studied. The diagram on the study evinces that the mainstream media is not well perceived by the majority of the educated Dalit (Kumar.S 2014). 


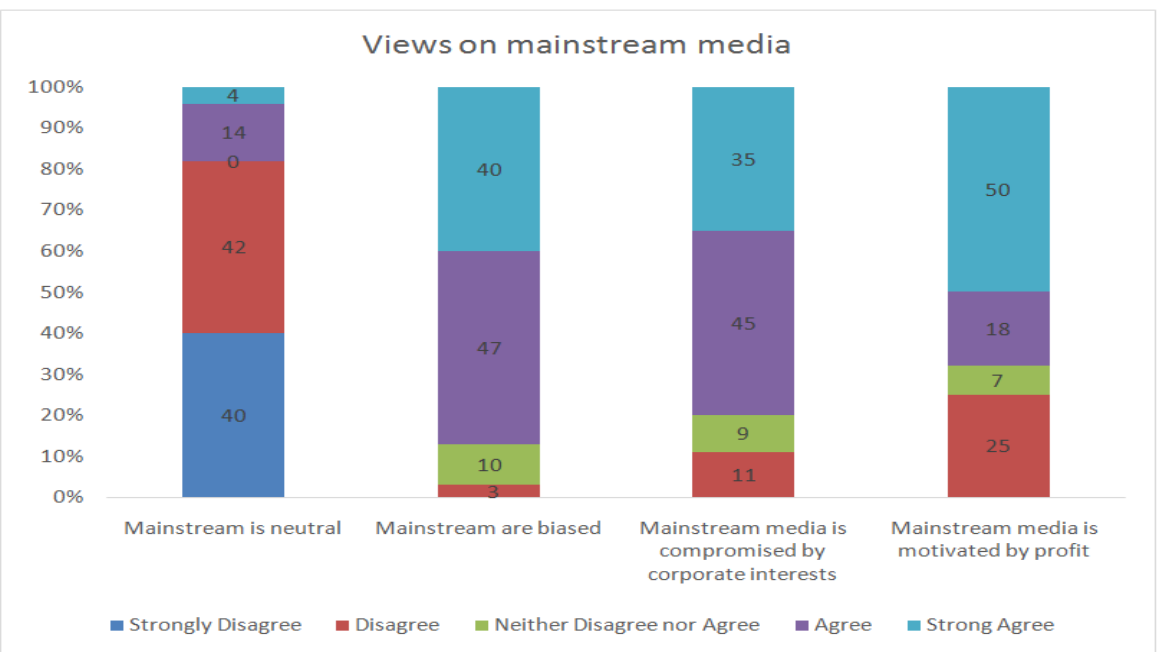

Figure-1 views on mainstream media

The bar chart above clearly conveys the message that mainstream media has produced a negative image about itself in the mind of Dalits particularly, educated Dalits. Majority of the respondents of the online survey disagree that mainstream media is neutral in its coverage. Similarly, $87 \%$ of them support the view that mainstream media is biased, $80 \%$ of them deem the mainstream media as compromised by corporate interests and $78 \%$ of the them say that mainstream media is motivated by profit.

Varadarajan (2006) in his article on Caste matters in the media writes about his experience on how the story of atrocity committed on Dalit students was not heeded by the media. He narrates that only after a lot of struggle he managed to publish only a part of the story "in a cut and mutilated form, a full month after the Dalit students began their dharna". Further, he says that absence of Dalits in the media industry is one of the reasons as to why there are no reports about Dalits in the Indian media (Varadharajan, 2006). In a talk show called Media Manthan on Dalit and media, Chawla (2012), Editorial Director of The New Indian Express accepts the absence of Dalits in the media. But he defends in the show that the caste bias in the media is not premeditated or any conspiracy hatched to avoid Dalits from entering the media industry. This is not an acceptable statement as one reads Balasubramanian's experience about his deliberate rejection by the editor of a Tamil newspaper in his research paper (Balasubramaniyam, 2011). This sort of attitude toward Dalits is nothing new from the fact that no Dalit journalists were allowed to enter the media world. In 1996, B.N Uniyal, a senior journalist in The pioneer, was confronted by a foreign journalist who wanted to get an opinion from a Dalit journalist over the reported dispute between Kanshi Ram, the founder of BSP and a few journalists. In an effort to find a Dalit journalist and to help the foreign journalist he started searching for a Dalit journalist. Faced with an utter failure in finding a Dalit journalist he writes, "Suddenly I realized that in all the 30 years I had worked as a journalist, I had never met a fellow journalist who was a Dalit; no, not one".

\section{Internet as alternative media for Dalits}

Researchers have conducted only a few studies specifically on Dalits and their access to internet and the digital divide Dalits face in the rural India. A recent report from Internet and mobile Association of India (IAMAI), says that the number of rural internet users has increased from 29 million as of December 2011 to 38 million at the end of June, and is expected to reach 45 million by the end of December this year. This statistics is against the 150 million total users to by the end of December 2012. (Internet and Mobile Association of India, 2012). The census of India 2011 report shows that rural population in India is $68.84 \%$ and the urban population is $31.16 \%$. Since the arrival of internet in India till now, the percent of internet user in rural India always remained low. The report on the usage of rural and urban internet usage make the point crystal clear: digital divide persists in India. Dalit who are mostly residing in villages are succumbed to digital divide.

Tiruamal and Tartakov (2011) in their research paper talk about the existence of significant opportunity that information technology and the internet in particular, available even to Dalits, the most marginalized community of India to take part in the national discourse of civil society and to have discourse among themselves. Furthermore they contend that the Internet has opened spaces in the walls of the caste system and the class system. Tiruamal and Tartakov (2011) argue:

Through these openings a small but vigorous group of Dalits are using information technologies to transcend barriers of caste in ways not possible before, and thus to take advantage of democratic opportunities that can lead to breaking through caste and the ritual walls to share understandings and interests with each other and from those who have previously been beyond their reach. 
Chopra (2006) in his study on virtual identity in online Dalit discourse, talks about the technology i.e internet which has enabled the emergence of a new mode of representing collective identity which he calls it as "Global Primordiality". He goes on to say that one of the main reasons as to why the number of Dalits found online remains very low is the domination of upper caste in the digital technology. Omvedt opines "Upper- caste dominance in the profession, business, culture and the world of computer technology." She continues to say that private sectors in IT firms are reluctant in adopting affirmative action policies to increase Dalit presence and Indian cyberspace is populated with Indian elite (Omvedt, 2001).

Though there exists digital divide among those at the bottom of the class system, there is significant number of individuals, social and transcendental (religious) - of the few thousand mostly, if not exclusively, male Dalits from this population who have acquired access to internet (Tirumal\&Tartakov, 2011). Further they discuss the potential of internet to Dalits as it makes visible of their plight to "other castes" from Dalit point of view as they never could before, while some Dalits have been allowed to see and learn from the ruling classes heretofore beyond their view. More important, Dalits have found a means of communicating with each other beyond the control of others.

Among other factors such as shelter, economic livelihood, basic education, and unemployment; lack of knowledge in English prevents Dalits to access internet. Only a fraction of this vast socially disenfranchised urban and rural community has little presence in the public sphere. They are composed of almost exclusively of college-educated men with government job. As most of the Dalits speak only local language, this small segment of Dalits has taken up the English language for the discourse over the internet.

Thus internet creates a platform for the disenfranchised to communicate with the people in the world and to have negotiation with the global capitalist regime. We find Dalit websites though few, have been very powerful in defending the rights of Dalits and articulating the discriminatory practices based on caste. Most of these sites are either run by Dalit activists or Dalit organization (Tirumal, 2008). Meena Kandaswamy, a Dalit activist and writer writes in her websites:

But, the democracy to speak up and speak out ensured that I was back to blogging again. Big media houses which own the major publications rarely give opportunity to Dalit (ex-untouchable) writers, and there's an absence of Dalit/anti-caste writers who write in English. The elitist writers want to write the feel-good stuff, India Shining myths, and that's the work that gets into print. So, I wanted to tap the power and enormous outreach of the internet: how anyone can write and be read/heard in the virtual space. I was not writing because anyone was commissioning me, I didn't have to follow other people's diktats, I could speak my mind. Google and tagging ensure that I can get heard without having my own column in any newspaper. Sometimes it helped me bring some happenings to light— such as the recent inside story of Dalit students being beaten up at a law university in Chennai (the mainstream media merely reported it as a "clash" at first) and so on.

Hugo Gorringe a senior lecturer in Sociology, University of Edinburgh and author of 'Untouchable Citizens: The Dalit Panthers and Democratisation of Tamilnadu writes about the role of Dalit websites and blogs as an alternative media:

It is quite common to see an article circulated through Facebook, on blog and websites together with an analysis that highlights the bias within that piece or offers an alternate reading. In that sense Dalit blogs and sites act as a sort of counter-public.

With proliferation of new media technologies and the increasing embourgeoisment of newly educated Dalit-beneficiaries of post-independence affirmative action policies of successive government - Dalit activism is now increasingly web-based regularly updated websites such as www.ambedkar.org and others keep the world informed of the success and vicissitudes of the many Dalit battles against entrenched upper-caste hegemony in south Asia (Ganguly, 2005).

Among a number of Dalit websites, www.roundtableindia.co.in is a news and information portal championing for Dalits.

The online survey conducted on Dalit websites and blogs reveals the reasons for Dalits and Dalit activists for accessing Dalit online media. The findings in the below bar diagram divulge that majority of the respondents of the online survey use it as an alternative media either to advocate Dalit issues or to associate with the rest of the Dalit population (Kumar.S, 2014). 


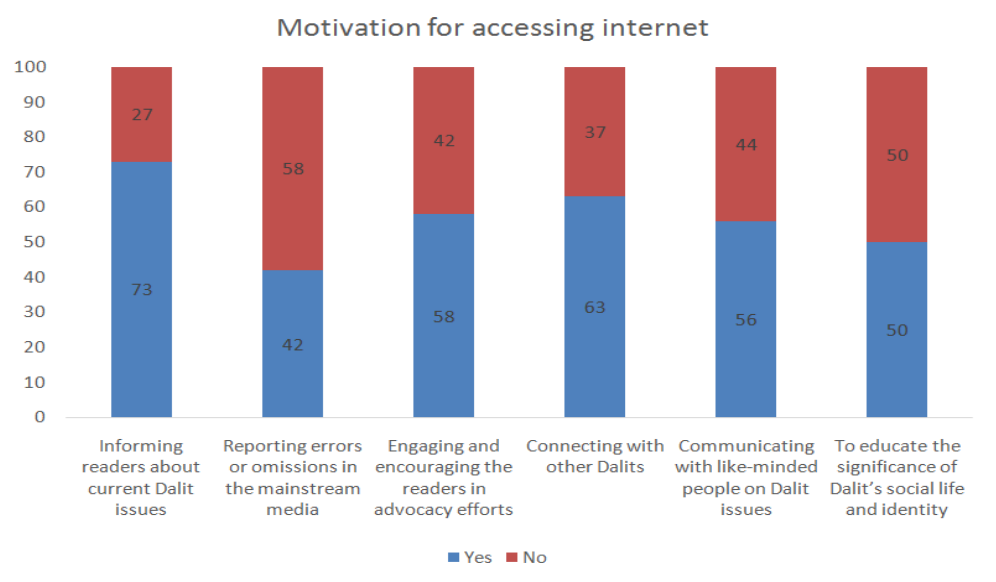

Figure - 2 motivations for accessing internet

Vanya Mehta, an independent journalist reports for BBC that Dalit Camera, a popular YouTube channel dedicated to India's Dalits, has become a rallying point for the community. She says:

Dalit Camera is an attempt at a historical documentation of the realities of life in India "through the eyes of the untouchable". (Vanya Mehta, BBC, 7January 2014).

Bathran Ravichandran, a doctoral student of English at the English and Foreign Languages University (EFLU) in Hyderabad is the man behind who conceived the idea of filming the plights of Dalits in India. Hailing from Tamil Nadu, he was the first from his caste in his district to receive higher education. It is noteworthy to mention that he comes from the "manual scavenging" caste, those who remove human excrement with their barehands. He says that the mainstream media did not give any exposure to the Dalit movements and atrocities, so with the help of Dalit camera he decided to "give them a voice on the internet". Currently, the channel is run by 23 -member team equipped with four video cameras with about 1,400 subscribers. Some of the videos of Dalit Camera have been viewed more than 50,000 times. (ibid)

A poll to determine the Greatest Indian after Gandhi was conducted in conjunction with CNN-IBN and History18 Channels with BBC in 2012. People were invited to vote online at www.thegreatestindian.in or through a missed call for their favourite. In the poll Dr.B.R.Ambedkar was voted as the greatest Indian after Gandhi. Citing one of the reasons for Ambedkar's win Anand of Outlook says that the "victory" for Ambedkar is most likely a result of the presence of a burgeoning internet-savvy, mobile-wielding, dedicated Dalit middle class that is almost invisibly making its presence felt. He goes on to say that in spite of the fact that Dalits are kept away from mainstream media, the private sector and Indian universities, Dalits in India and abroad, have fashioned their own websites, mailing lists and blogs such as Roundtableindia, Dalit\&Adivasi Students' Portal and Savari, a YouTube channel called Dalit Camera, besides scores of Facebook groups. They no longer depend on corporate media. (Anand, 2012).

\section{Conclusion}

In India more than quarter of the population comprises of Dalits. In the past, Dalits have been neglected and discriminated by the mainstream media. But now, the scenario is gradually changing with more and more educated Dalits entering into the media industry. Though, Dalits entry into the mainstream media can be viewed positively, the kind of position they occupy in the media industry is not applaudable. There are also many instances where the persons are asked to divulge their caste identity. If the person is found from the low caste, then the discrimination follows again in the media too. Dalits are mostly perched in the lower hierarchy position in the newspapers and television channels. Only in recent days, the plights of Dalits have been noticed by the international media and also by the Indian media. Besides, the evolution of internet in India has become a great boon to Dalits, particularly to educated Dalits. With immense potentials, internet has paved way for Dalits to have their own media to speak and discuss the issues concerning Dalit community freely and openly. Though the mainstream media gives coverage Dalit issue now and then, they are miniscule in number. There are mammoth problems unnoticed and uncared by the mainstream media. In this scenario, Dalits are making use of this new medium to speak for themselves. Due to the negligence of the mainstream media in representing Dalit issues,Dalits have taken shelter under the alternative media like websites, online forums, blogs, Facebook, etc. Majority of the Dalit activists agree to the fact that internet like websites, online groups, forums and social networking sites as blogs and Facebook play the role of alternative media. Several studies have cited that Dalit activists view internet as the media, enabling and facilitating access and participation by the members of the community and the channel of communication for the stigmatized community. Further, an alternative media is 
considered as the media which can stand on par with the mainstream media and can offer a counter-hegemonic representation of Dalits. Thus, internet has become a tool for the marginalized Dalits to utilize it as an alternative media. Studies have provided evidence of the contribution of internet in educating, empowering and strengthening Dalit community they serve. Internet is acting as focal point for the members of the Dalit community to inform others about the day to day issues on Dalits and to get connected with each other.

\section{References}

[1] Anand, A. (2012). A Case for BhimRajya, retrived fromhttp://www.outlookindia.com/article.aspx?281949

[2] Balasubramaniam, J. "Dalits and a Lack of Diversity in the Newsroom."economic and political weekly 46.11 (2011).

[3] Chopra, Rohit. "Global primordialities: Virtual identity politics in online Hindutva and online Dalit discourse." New media \& society 8.2 (2006): 187-206.

[4] Ganguly, Debjani. (2005). Caste, Colonialism and Counter-modernity: Notes on a Postcolonial.

[5] Jeffrey, Robin. "India's Newspaper Revolution capitalism, politics, and the Indian-language press, 1977-99." (2003).

[6] Kumar.S (2014), Dalits and alternative media: a study on dalits' engagement in articulation of their voices in the indian blogs and web portals, Unpublished doctoral dissertation, Periyar University, Salem.

[7] Mehta. V (7January 2014), YouTube channel becomes rallying point for India's Dalits, BBC. Retrieved fromhttp//www.bbc.co.uk/news/world-asia-india25502849

[8] Ninan, S. (2007). Headlines from the heartland: Reinventing the Hindi public sphere. Sage.

[9] Omvedt, G. (2009). Untouchables in the World of IT.

[10] Prasad, Chandra Bhan. (2001). Body language of the Varna media.

[11] Ravikumar\&Rajan, Nalini, ed. 21st Century Journalism in India. Sage, 2007.

[12] Thirumal, P., and Gary Michael Tartakov. "India's Dalits search for a democratic opening in the digital divide." International exploration of technological equity and the digital divide: Critical, historical and social perspectives (2011): 20-39.

[13] Thirumal, P. (2008). Situating the new media: Reformulating the Dalit question. In R. Gajjala and V. Gajjala (Eds.), South Asian technospaces, Digital Formations, 36, New York: Peter Lang Verlag.

[14] Varadarajan, Siddharth. "Caste matters in the Indian media'." The Hindu 3 (2006). 